\title{
福岡市における雑用水利用の利水効果に関する 検討 \\ A STUDY ON THE EFFECT OF TREATED DOMESTIC WASTEWATER REUSE ON WATER UTILITIZATION IN FUKUOKA CITY
}

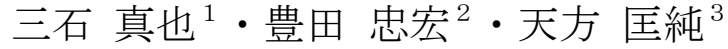 \\ Shinya MITSUISHI, Tadahiro TOYODA, Masazumi AMAKATA \\ ${ }^{1}$ 正会員 (独) 土木研究所 水災害・リスクマネジメント国際センター水災害研究グループ \\ （干305-8516茨城県つくば市南原1-6） \\ 2 正会員 国土技術政策総合研究所 水資源研究室 ( $305-0804$ 茨城県つくば市旭1番地) \\ 3 正会員 八千代エンジニヤリング株式会社 技術第一課 (†161-8575東京都新宿区西落合2-18-12)
}

\begin{abstract}
Recently, in the wake of drought occurrence, the necessity of promoting comprehensive water resources development not only including river water, also groundwater and reuse of treated domestic wastewater has pointed out. Regarding reuse of treated domestic wastewater, as its water resources is relying on rain water and life sewage water, in case of drought, it has lower safety degree of water use due to scarce rainfall and the implementation of water conservation. This study shows the safety of water utility about the reuse of treated domestic wastewater. We have modeled the status of Fukuoka City water project promoting the use of reclaimed wastewater and the rainwater utilization. We numerically evaluate the effects of reuse of treated domestic wastewater and estimated the available amount of it in the future.
\end{abstract}

Key Words : reuse of treated domestic wastewater, rainwater utilization, reclaimed wastewater, safety of water utility, drought

\section{1. はじめに}

雨水や下水再生水を活用寸る雑用水利用は，河川水や 地下水とともに陸水の水循環を構成する貴重な水源とし て位置づけられている1)，その意義は，利水安全度の向 上，災害時の緊急用水，渴水時の代替水源のほか，公共 用水域の水質改善効果 ${ }^{2}$, 洪水被害の低減 ${ }^{3)}$ ，水辺の再 生 ${ }^{4)}$, 水生生物の生息場所の確保など多面的である ${ }^{5}$. こ れらのうち利水面にあっては，近年，渴水の発生を期に， 河川水のみならず，地下水，雑用水利用などを含む総合 的な水資源開発を推進する必要が指摘されている ${ }^{6}$. こ こに雑用水利用は，水源を雨水や生活雑排水に依存寸る ことから，渴水時において降雨の減少や節水の実施に付 随寸る排水量の減少によって利水安全度が低下寸る短所 を有しているが，これらの水資源供給能力について，地 域の水需給バランスの観点を踏まえつつ定量的に明らか にした研究は少ない. このため, 本研究では, 雑用水利 用の効用のうち利水面に焦点を当て, 雑用水利用を推進 している福岡市を対象としてモデル化を行い，雑用水利
用の利水効果について定量的な評価を行うとともに，将 来利用可能量の推定を行ったものである.

\section{2. 雑用水利用のモデル化}

雑用水利用の利水効果について研究した事例として, 和田ら》は, 雨水利用について, 事務所ビルであるパイ ロット実験施設を対象にシミュレーションを実施し，雨 水利用率を算定するとともに，モデル地区における雨水 利用効果を算出した。 また, 和田ら ${ }^{8)}$, 雨水利用及び 個別循環方式について，モデル流域の下水道整備地域を 対象に水資源としての評価を行うとともに，河川区域一 の污濁負荷量の削減効果を算定した。 江藤ら ${ }^{9}$ は, 雨水 利用施設の利水効果について, 污濁負荷の公共用水域一 の流入削減効果を表現する式により評価している。ここ に，将来を見通した合理的かつ総合的な水資源開発施策 の展開，才なわち，ダムや地下水，雑用水利用等を適切 に組み合わせた水資源開発計画を策定するためには，計 画策定区域を対象とした渴水時における雑用水利用の供 
給能力評価と施設数の正確な予測が不可欠である.この ため，特定の行政区域全域における雑用水利用施設の導 入状況を把握し，将来見通しを正確に推計するとともに， 渴水時における各施設における利用量をダムの利水計算 精度と類似した精度で明らかにする必要がある。本研究 においては，雑用水利用のうち，福岡市において，今後 も導入が見込まれる雨水利用と閉鎖系循環方式について 現存するデータを活用しつつ，分析を行うこととした. 一戸建て住宅における雨水利用については，福岡市にお ける住宅に関するデータを参考にしつつ，モデル化を行 うとともに，渴水年，平水年における利用可能量につい てシミュレーションを実施した．ビルにおける雨水利用 については，一戸建て住宅と同様にモデル化を行い，下 水再生利用については，福岡市，国土交通省の統計デー 夕を参考にしつつ，ビルの用途別に分類し，渴水時にお ける上水道の節水率も考慮して使用水量を算出した. そ して, 雑用水利用のこれまでの整備状況から回帰式を算 出して，10年後における施設整備数と利用量を推計した. 以下に詳細に分析手法を示す.

\section{3. 一戸建てにおける雨水利用}

\section{(1) 一戸建て雨水利用のモデル}

雨水利用は，間欠的な降雨に頼らざるを得ない面を持 つため，渇水時においては，降雨量が減少し，その効果 が十分に発揮できないことが危惧されることを踏まえ， 本研究では平水年のみならず, 渴水年をも対象としたシ ミュレーションを実施した. 雨水貯留施設のモデルは図 - 1 に示寸とおりであり，屋根に降った降雨が集水され， 降雨: $R\left(m^{3} /\right.$ 日)

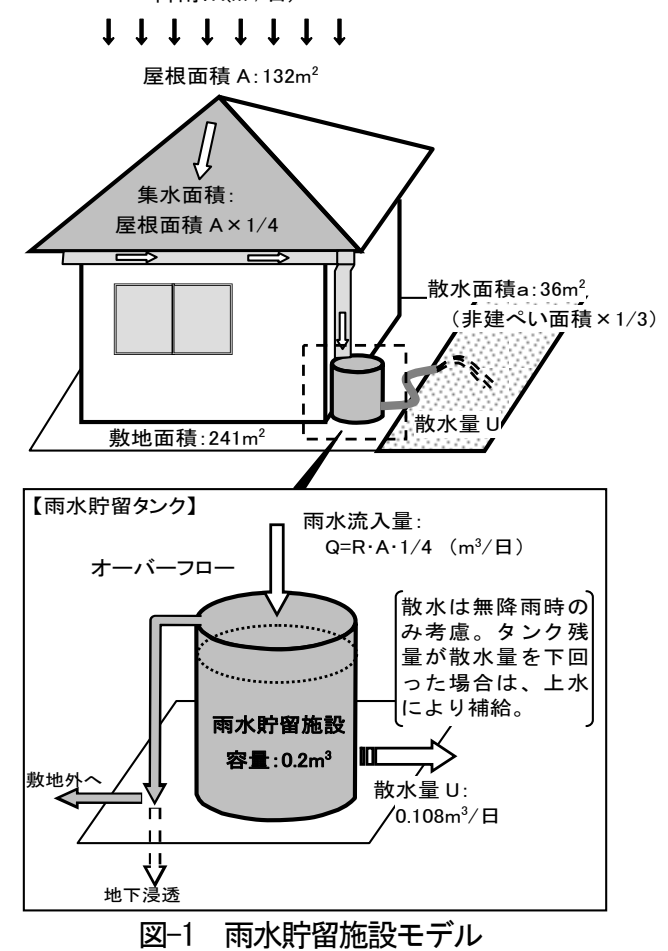

雨樋から雨水タンクに貯留される. タンク容量を超えた 量は，オーバーフローし河川に放流される構造となって いる. モデルの各諸元は，図-1に示すとおりであり，屋 根面積は, 敷地面積, 建ぺい率を参考に設定し, これら は福岡市の統計值に基づく值を採用した.

雨水の利用用途としては, 福岡市における行政指導を 踏まえて，「庭への散水」のみを計上し，散水量は「雨 水利用ハンドブック（社）雨水貯留浸透技術協会」 ${ }^{10)}$ の 值を基に，1日あたり $0.003 \mathrm{~m}^{3} / \mathrm{m}^{2}$ とした。ここでは，降 雨時には雨水の貯留を行い，無降雨時にのみ雨水利用を 行う計算としている，以上によりモデルを設定し，雨水 貯留による利水効果の計算を実施した.

\section{(2) 雨水貯留による利水効果の評価}

福岡市において平水年であるH21年のほか，過去に渇 水が発生したS53，H6，H14年を対象として，1戸あたり の雨水利用の効果について計算した. 寸なわち，1戸当 りの利用水量についてはH20年度で固定し, 過去に発生 した渴水年，平水年等の降雨が生起したと仮定して，各 年の降水量を基に敷地内の降雨量を与え，モデルにより 利用可能となる雨水量を算定した。計算結果を表- 1 に 示す. 敷地内の降雨の $2.3 \sim 3.4 \%$ に相当する雨水を利用 できる結果となった.

渴水年においては，1年間における雨水利用量は，1戸 あたり $7.20 \mathrm{~m}^{3} /$ 年 $~ 8.87 \mathrm{~m}^{3} /$ 年であり，雨水タンクによっ て, 散水量全体の $24.3 \sim 34.1 \%$ 賄える結果となってい る. 一方，平水年である $\mathrm{H} 21$ 年では $35.3 \%$ 占める. こ こに渴水年における雨水利用を平水年と比較すると, 渴 水年は散水量全体に対する雨水タンク利用量の占める率 が1〜11\%低下する結果となっている. この原因として は，水源となる降雨の影響が考えられる，図-2に毎日の 降雨量と雨水散水利用状況について，H6年7月とH21年7 月を比較したものを示す．なおここでは，7月は高温で あることを踏まえ，降雨の分布に係わらず無降雨日には 散水を行うこととした.

H21年7月は降雨量が多く, かつ頻繁に降雨が発生し ているため, タンクへの雨水貯留が効率よく行われてお り，雨水利用も15日に及ぶなど高い利用効果が得られて いる. 平成6年7月のような降雨量の少なく，かつ2日し

表-1シミュレーション計算結果

\begin{tabular}{|c|c|c|c|c|c|c|c|c|}
\hline 対象年 & $\begin{array}{l}\text { 敖地内 } \\
\text { 降雨量 } \\
\left(\mathrm{m}^{3} / \text { 年 }\right) \\
\end{array}$ & $\begin{array}{c}\text { 1戸当り } \\
\text { 利用水量 } \\
\left(\mathrm{m}^{3} / \text { 年 }\right)\end{array}$ & $\begin{array}{l}\text { 総散水量 } \\
\left(\mathrm{m}^{3} / \text { 年 }\right)\end{array}$ & $\begin{array}{c}\text { 雨水 } \\
\text { 散水量 } \\
\left(\mathrm{m}^{3} / \text { 年 }\right) \\
\end{array}$ & $\begin{array}{c}\text { 上水 } \\
\text { 補給量 } \\
\left(\mathrm{m}^{3} / \text { 年 }\right)\end{array}$ & $\begin{array}{c}\text { 雨水散水量 } \\
\text { /総散水量 } \\
(\%) \\
(\%)\end{array}$ & $\begin{array}{c}\text { 雨水散水量 } \\
/ \text { 敷地内内降雨 } \\
\text { 量 } \\
(\%) \\
\end{array}$ & $\begin{array}{c}\text { 雨水散水量 } \\
\text { /総利用水量 } \\
(\%) \\
(\%)\end{array}$ \\
\hline 昭和 53 年 & 274.3 & \multirow{4}{*}{211.1} & 27.3 & 8.78 & 18.5 & 32.1 & 3.2 & 4.2 \\
\hline 平成 6 年 & 214.7 & & 29.6 & 7.20 & 22.4 & 24.3 & 3.4 & 3.4 \\
\hline 平成14年 & 330.5 & & 26.0 & 8.87 & 17.2 & 34.1 & 2.7 & 4.2 \\
\hline 平成 21 年 & 407.8 & & 26.5 & 9.33 & 17.1 & 35.3 & 2.3 & 4.4 \\
\hline
\end{tabular}



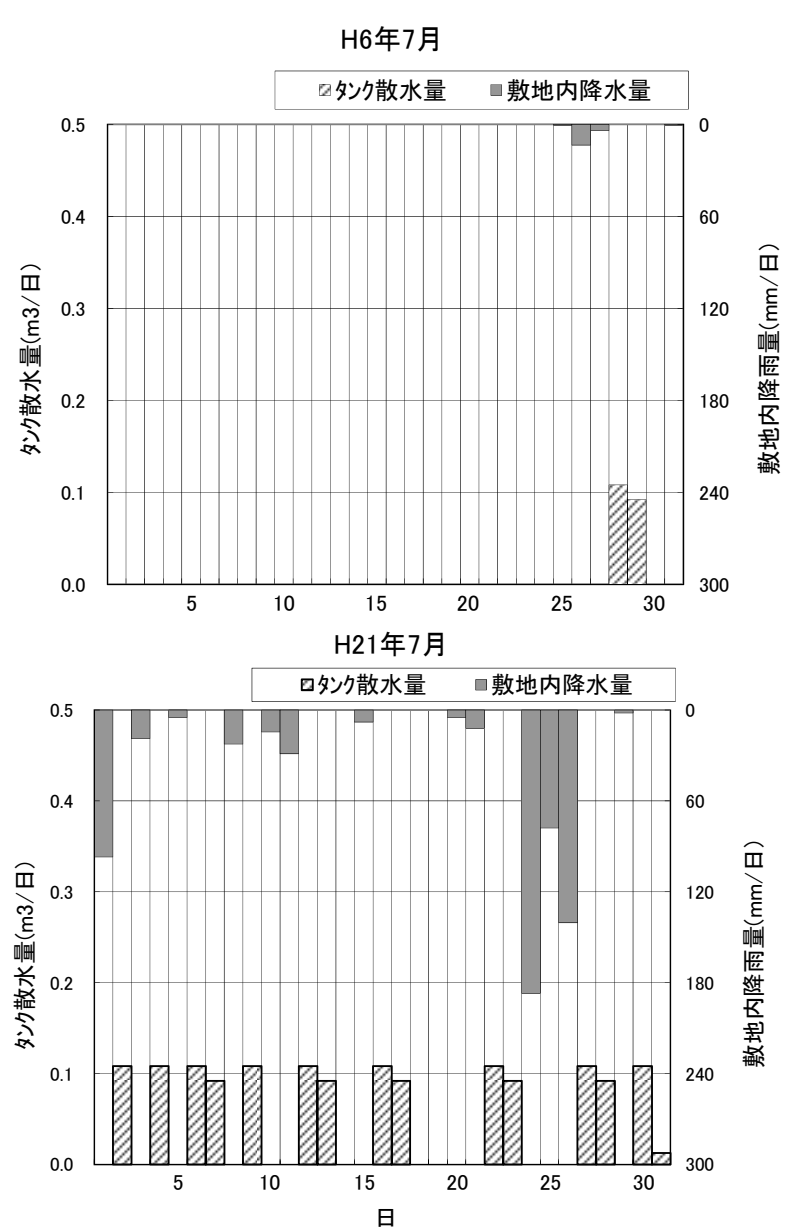

図-2 日降雨量と雨水散水利用状況

(平成6年7月, 平成21年7月の比較)

か降雨のない月においては，ほとんど雨水貯留が行えな いため, 雨水利用が行える日が少なく, 利用効果も低迷 している.

図-3に月間降雨日数と月間雨水散水量の関係を示寸. この図からも，降雨日数が多くなるに従って，雨水利用 量が増加することが理解できる.

また，月降雨量が多い場合でも，タンクへの貯留量に 制限があるため, 降雨が頻繁に発生すれば利用効果が向 上寸るが，降雨が特定の日に集中寸るとほとんどが無効 放流となるため，利用効果が低下寸ると考えられる.

敷地内降雨量は，平水年である平成21年の方が平成14 年に対して $77.2 \mathrm{~m}^{3}$ (23\%) 多いが，タンク散水量として は， $0.46 \mathrm{~m}^{3}$ と5\%の増加に留まっている.

このように，雨水貯留による効果は，降雨への依存性 が非常に高いものの，一戸当たりの水道総利用水量に対 する効果は， $3.4 \%$ ～ $4.4 \%$ と一定の水準を保つ. 特に平 成21年7月のように降雨に恵まれた時期においては, 7.8\%を占める.

ここでは，(2)までの各戸における雨水利用量の推計を 活用し，福岡市における導入状況から将来の雨水利用量 を予測した. これまでの雨水貯留施設の導入家屋は図-4
に示すとおりであり，平成21年現在，695戸に導入され ている.これまでの導入実績からその傾向を回帰式にて 求め, 将来10年程度の限られた期間内での近似的予測を 行うにあたり, 次式を得た。

$$
\begin{gathered}
\mathrm{Y}=131.64 * \mathrm{X} \\
\text { ここに, } \mathrm{Y}: \text { 導入家屋数 } \\
\mathrm{X}: \mathrm{H} 16 \text { 年度を基準とした年数 }
\end{gathered}
$$

(1)式から10年後の平成31年における導入家屋数を推計 すると1,975戸となる. (2)で求めた雨水散水量に家屋数 を乗じて福岡市全体の雨水散水量を求めると表-2のとお りであり, 福岡市の上水道需要量約 145 百万 $\mathrm{m}^{3} /$ 年（平成 20年度）に対する雨水利用量の割合は， $0.01 \%$ 程度に留 まる．これは，福岡市の人口が140万人余りである一方 で，導入家屋数が小さいことによるものと考えられ，福 岡市全体の水道需要量に対寸る効果は極めて小さく, ダ

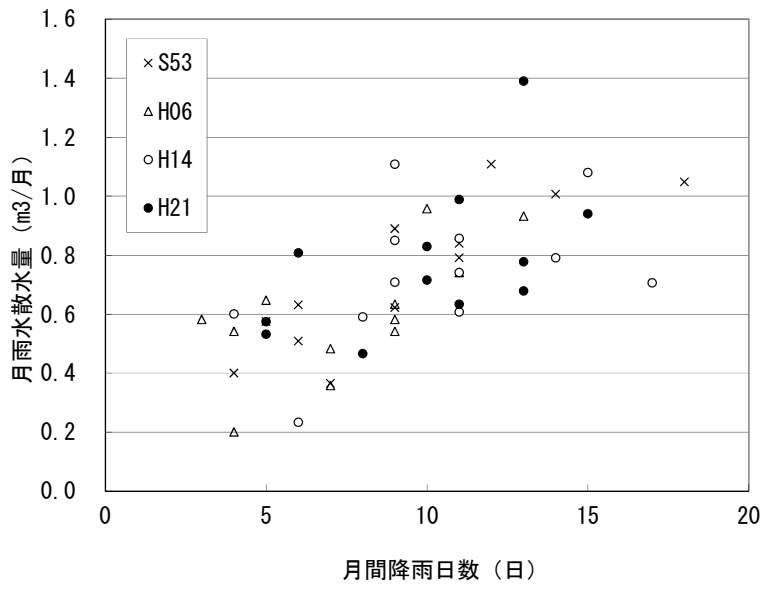

図-3 月間降雨日数と月間雨水散水量

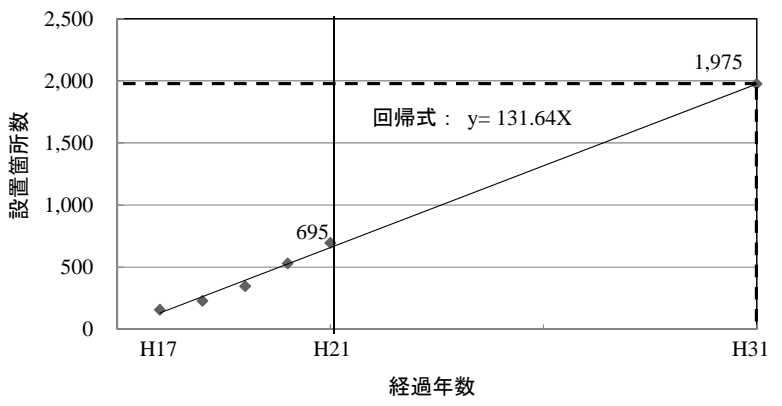

\begin{tabular}{|c|c|c|c|c|c|c|c|}
\hline 対象年 & $\begin{array}{l}\text { 敷地内 } \\
\text { 降雨量 } \\
\left(\mathrm{m}^{3} / \text { 年 }\right)\end{array}$ & $\begin{array}{l}\text { 総散水量 } \\
\left(\mathrm{m}^{3} / \text { 年 }\right)\end{array}$ & $\begin{array}{c}\text { 雨水 } \\
\text { 散水量 } \\
\left(\mathrm{m}^{3} / \text { 年 }\right)\end{array}$ & $\begin{array}{l}\text { 水道水 } \\
\text { 散水量 } \\
\left(\mathrm{m}^{3} / \text { 年) }\right.\end{array}$ & $\begin{array}{c}\text { 雨水散水量 } \\
\text { /総散水量 } \\
(\%) \\
(\%)\end{array}$ & $\begin{array}{c}\text { 雨水散水量 } \\
\text { /敷地降雨量 } \\
(\%) \\
(\%)\end{array}$ & $\begin{array}{c}\text { 雨水利用量 } \\
\text { 上水給水量 } \\
(\%)\end{array}$ \\
\hline 昭和53年 & 541,660 & 53,965 & 17,354 & 36,611 & 32.1 & 3.2 & $0.012 \%$ \\
\hline 平成6年 & 424,094 & 58,444 & 14,211 & 44,233 & 24.3 & 3.4 & $0.010 \%$ \\
\hline 平成 14 年 & 652,800 & 51,405 & 17,518 & 33,887 & 34.1 & 2.7 & $0.012 \%$ \\
\hline 平成 21 年 & 805,350 & 52,259 & 18,429 & 33,830 & 35.3 & 2.3 & $0.013 \%$ \\
\hline
\end{tabular}

図-4 将来の雨水貯留施設数推定

表-2 将来施設推計による雨水利用率 (10年後) 
ム等水資源開発施設の代替案とはなり難い.ここに，ダ ムと同等になるためには，規制の導入により全家屋に雨 水タンクを設置させるほどの変化が必要であり，それは 非現実的である.

\section{4. ビルにおける雨水利用と下水再生利用}

\section{(1) 閉鎖系循環方式の推計方針}

閉鎖系循環方式の大部分を占める施設は，ビルにおけ る雑用水利用であり，詳細には個別循環方式，地区循環 方式，広域循環方式に区分される．福岡市においては， 平成24年までに地区循環方式を廃止する予定であり，そ の後も新設の予定はない，このため, 本研究では, ビル においては, 雨水利用のほか下水再生利用として, 個別 循環方式と広域循環方式について, 利用量を推計するこ ととした.

\section{(2) 個別循環方式利用量の推計}

\section{a)平常時の雑用水利用量の推計}

国土交通省水資源政策課は，雨水・下水再生水利用の 課題及び今後の施策の方向性をとりまとめることを目的 として, 雑用水利用の普及状況の実態を調査している ${ }^{11)}$ その調査内容は, 建物利用用途, 延床面積, 下水再生水 利用量, 雨水利用量などである. また, 福岡市も同様に 調査を実施し，一定の情報を得ている．調査により把握 している施設数は，それぞれ205施設，290施設であり， ここでは，福岡市資料が国土交通省資料を包含するもの と仮定して取り扱った.

国土交通省資料は，施設内利用量について，162施設 についてのみデータを有しており，43施設については， 不明としている。ここでは, 福岡市全体290施設の利用 量を次の手順により分析した.

1) ビル別に年単位水量を稼働日数で除して, 日単 位利用量を算出寸る.

2) 雑用水利用量は, ビルの利用用途により, 大き く異なり，使用水量は延床面積に比例するとの 仮説を立て，用途別に延床面積，使用水量の回 帰式を求め (図-5 参照 但し施設数が 3 施設以 上の用途に限る）使用水量が不明なビルについ て推計した.

3）福岡市資料のみが把握している 85 施設の使用水 量については，延床面積が不明であるため，用 途別に施設数で補完することとし，用途別の平 均床面積を用いて使用水量を算出した.

一例として, 図-5にホテルにおける延床面積と雑用水 利用量の関係を示寸.また，表-3に個別循環方式利用量 の推計を示寸.

b)渴水時の雑用水利用量の推計

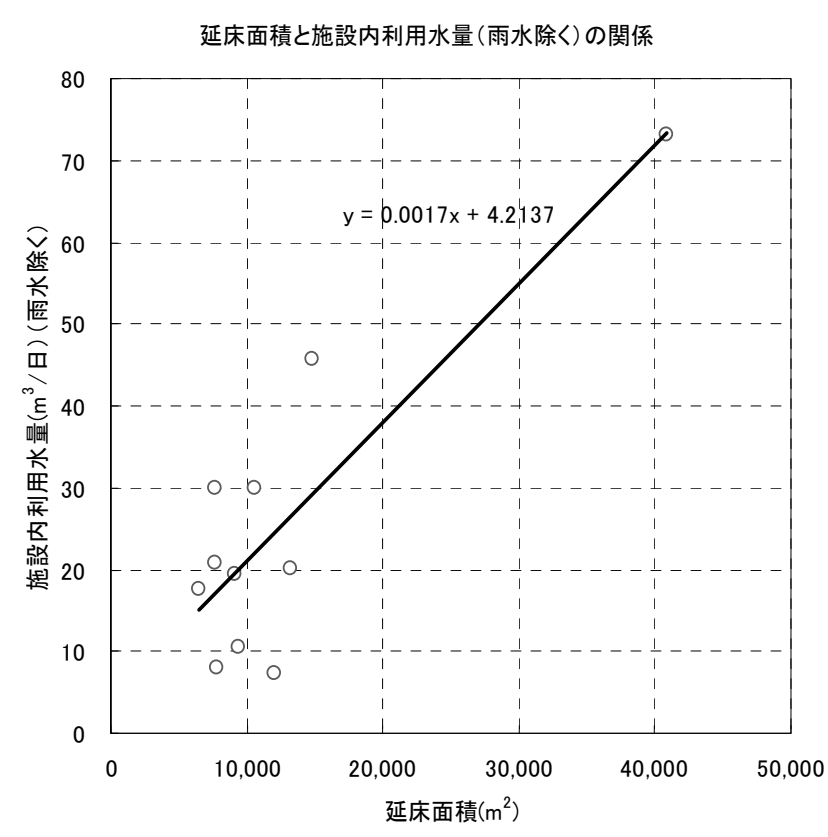

図-5 延べ床面積と雑用水利用の関係 (ホテルにおける例)

表-3 個別循環施設内雑用水利用量

\begin{tabular}{|c|c|c|c|c|c|}
\hline 個別循環用途別施設名 & $\begin{array}{c}\text { 施設内 } \\
\text { 利用水量 } \\
\mathrm{C}_{i}\left(\mathrm{~m}^{3} / \text { 年 }\right)\end{array}$ & \begin{tabular}{c|} 
標本 \\
施設数 \\
$n_{i}$
\end{tabular} & $\begin{array}{c}\text { 実態 } \\
\text { 施設数 } \\
f_{i}\end{array}$ & $\begin{array}{c}\text { 補正率 } \\
f_{i} / n_{i}\end{array}$ & $\begin{array}{l}\text { 補正後施設内 } \\
\text { 利用水量 } \\
\mathrm{C}_{\text {ih }}\left(\mathrm{m}^{3} / \text { 年) }\right.\end{array}$ \\
\hline 事務所ビル & 152,979 & 89 & 94 & 1.06 & 161,573 \\
\hline 学校 & 205,217 & 54 & 86 & 1.59 & 326,828 \\
\hline 医療·福祉機関 & 239,457 & 18 & 21 & 1.17 & 279,366 \\
\hline 百貨店·スーパー & 83,666 & 8 & 22 & 2.75 & 230,081 \\
\hline ホテル & 206,889 & 14 & 21 & 1.50 & 310,333 \\
\hline 体育館 & 8,481 & 5 & 14 & 2.80 & 23,747 \\
\hline 駅·空港·バスターミナル & 138,714 & 2 & 5 & 2.50 & 346,785 \\
\hline 工場 & 27,625 & 3 & 6 & 2.00 & 55,250 \\
\hline その他施設 & 10,334 & 6 & 21 & 3.50 & 36,169 \\
\hline 合計 & $1,073,362$ & $199 *$ & 290 & - & $1,770,132$ \\
\hline
\end{tabular}

渴水時には, 給水制限に伴って雑用水の水源である雑 排水が減少し, これに伴って雑用水利用量も減少すると 考えられる. 渴水時における日単位での雑用水利用量は, 統計として把握されていないため, ここでは, 給水制限 がそのまま雑用水利用量に反映すると仮定して, 次式に より利用量を求めた.

$$
\mathrm{Y}=\left(1-\frac{\mathrm{pD}}{365 \times 100}\right) \times \sum \mathrm{C}_{\mathrm{i}}
$$

ここに，Y: 取水制限を考慮した年間施設内利用水量 


\section{$\mathrm{p}$ : 給水期間内平均給水制限率 \\ $\mathrm{D}:$ 給水制限日数 \\ $\mathrm{Ci}$ : 用途別施設内利用水量}

a)の結果と(2)式を組み合わせることにより，渴水時にお ける雑用水利用量は表-4のとおりと推計された。昭和53 年，平成6年の渇水時においては，平常時の約 $80 ９ 0 \%$ の利用水量となるものと推計された.

c)雨水利用量の推計

国土交通省資料 ${ }^{11)}$ にれば，個別循環方式205施設の うち18施設で雨水利用が行われている。 これらを建物用 途により事務所ビル，学校, 商業施設に区分するととも に，図-1と同様の雨水貯留モデルを作成し，代表する5 つの施設について平水年及び渇水年を対象としたシミュ レーションを実施した．さらに，延床面積と雨水利用量 の相関性が高いことを利用し，建物用途毎に延床面積に 基づき残る13施設の雨水利用量を算出した. 結果は, 表 -5に示寸とおりであり，56〜 79千 $\mathrm{m}^{3} /$ 年の利用量と考え られる.

\section{（3）広域循環方式利用量の推計}

福岡市において，広域循環方式を採用している施設は， 中部再生水処理施設及び東部再生水処理施設であり, そ れぞれ $4,700 \mathrm{~m}^{3} /$ 日， $120 \mathrm{~m}^{3} /$ 日の下水再生水を利用してい る. これらの水量は, 当該施設における下水処理量の 1/10以下の水量であるため, 渇水時においても水源不足 の恐れはないことは自明である.

表-4 渇水時における雑用水利用量

\begin{tabular}{|c|c|c|c|c|}
\hline 対象年 & $\begin{array}{c}\text { 平常時施設内 } \\
\text { 利用水量総計 } \\
\left(\mathrm{m}^{3} / \text { 年 }\right)\end{array}$ & $\begin{array}{c}\text { 給水制限日数 } \\
(\text { 日 })\end{array}$ & $\begin{array}{c}\text { 給水制限期間内 } \\
\text { 平均給水制限率 } \\
(\%)\end{array}$ & $\begin{array}{c}\text { 渇水時の施設内 } \\
\text { 利用水量総計 } \\
\left(\mathrm{m}^{3} / \text { 年 }\right)\end{array}$ \\
\hline 昭和53年 & $1,770,132$ & 197 & 38.8 & $1,399,832$ \\
\hline 平成6年 & $1,770,132$ & 150 & 25.3 & $1,585,757$ \\
\hline 平成14年 & $1,770,132$ & 0 & 0.0 & $1,770,132$ \\
\hline
\end{tabular}

表-5 個別循環施設雨水利用量

\begin{tabular}{|c|c|c|c|c|}
\hline \multirow{3}{*}{ 施設用途 } & \multicolumn{4}{|c|}{ 雨水利用水量 } \\
\hline & \multicolumn{3}{|c|}{ 渇水年 } & 平水年 \\
\hline & $\begin{array}{c}\text { S53年 } \\
1,138 \mathrm{~mm}\end{array}$ & $\begin{array}{c}\text { H6年 } \\
891 \mathrm{~mm}\end{array}$ & $\begin{array}{c}\text { H14年 } \\
1,372 \mathrm{~mm}\end{array}$ & $\begin{array}{c}\text { H20年 } \\
1,781 \mathrm{~mm}\end{array}$ \\
\hline 学校（7施設） & 11,082 & 9,727 & 10,536 & 10,872 \\
\hline 事務所ビル（8施設） & 11,986 & 11,927 & 13,240 & 13,038 \\
\hline その他 (車庫·車両基地) & \multirow{3}{*}{55,408} & \multirow{3}{*}{46,511} & \multirow{3}{*}{54,140} & \multirow{3}{*}{55,286} \\
\hline その他 (医療·福祉機関) & & & & \\
\hline その他 (百貨店・スーパー) & & & & \\
\hline 18施設合計 & 78,476 & 56,238 & 77,916 & 79,196 \\
\hline
\end{tabular}

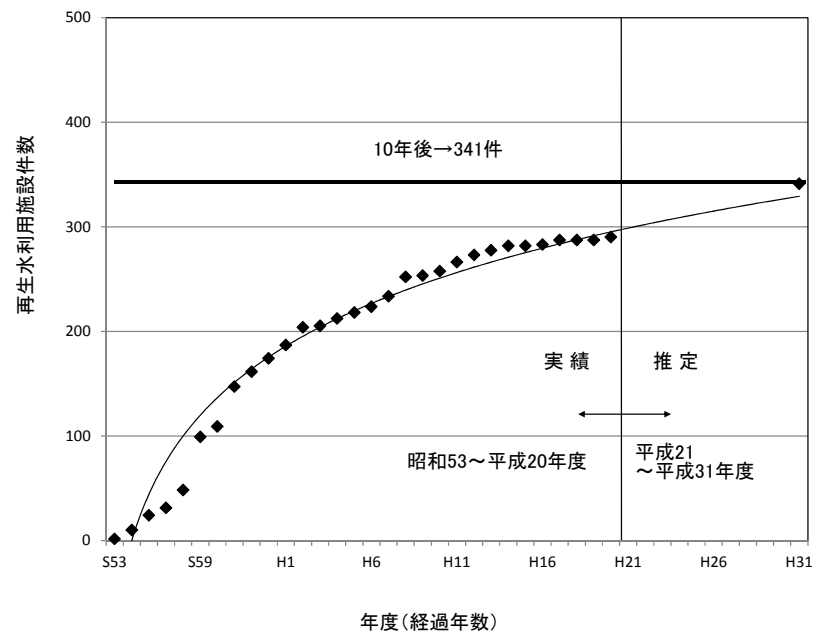

図-6 将来の再生処理施設数推定（個別循環施設）

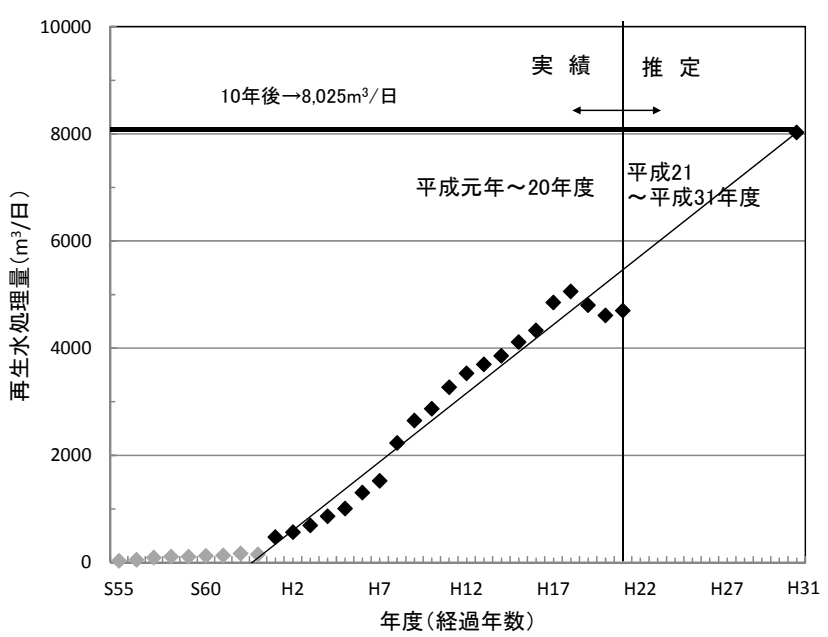

図-7 将来の再生処理施設数推定（広域循環施設）

\section{（4）現況及び将来における雑用水利用量}

(2), (3)の結果を合計すると現況施設による雑用水利用 量は，年によって若干の差異はあるものの，表-6に示す とおり, 約328〜 366万 $\mathrm{m}^{3} /$ 年であり，上水道給水量の 2.26〜 2.52\%に相当する. 昭和53年において最も厳しい 給水制限を実施していた6月において最小の上水給水量 は196,386m³/日であり，当該日において雑用水利用 は, $4.58 \%$ の供給を占める.

また，平成31年における雑用水利用を推計するために， 図-6,7に示すように, 平成20年までの施設整備数の推移 から回帰式を算出し，平成31年度における施設数を推計 した.

雑用水利用量は施設数に比例して増大寸ると仮定して, 平成31年度における利用量を表-6のとおり推計した。 平 成21年からの雑用水利用の増量は，1,440～1,500千 $\mathrm{m}^{3}$ で あり，上水道給水量の $1 \%$ 程度に相当する. これに対し て，福岡市が取水を予定している五ヶ山ダムは15,100千 $\mathrm{m}^{3}$ の利水容量を有しており, ダム建設に伴って, 平常時 においては河川自流の取水が可能となることを加味すれ 
表-6 雑用水利用率の推計

\begin{tabular}{|c|c|c|c|c|c|c|c|}
\hline \multirow{3}{*}{$\begin{array}{l}\text { 評価 } \\
\text { 対象 }\end{array}$} & \multirow{3}{*}{ 対象年 } & \multicolumn{3}{|c|}{ 雑用水利用量 } & \multicolumn{3}{|c|}{ 雑用水利用量/上水給水量 } \\
\hline & & 個別循環 & 広域循環 & 合計 & 個別循環 & 広域循環 & 合計 \\
\hline & & $\left(\mathrm{m}^{3} /\right.$ 年) & $\left(\mathrm{m}^{3} /\right.$ 年 $)$ & $\left(\mathrm{m}^{3} /\right.$ 年 $)$ & (\%) & $(\%)$ & $(\%)$ \\
\hline \multirow{4}{*}{$\begin{array}{l}\text { 1) } \\
\text { 現 } \\
\text { 況 } \\
\text { 施 } \\
\text { 設 }\end{array}$} & 昭和53年 & $1,525,568$ & $1,759,300$ & $3,284,868$ & 1.05 & 1.21 & 2.26 \\
\hline & 平成 6 年 & $1,693,950$ & $1,759,300$ & $3,453,250$ & 1.17 & 1.21 & 2.38 \\
\hline & 平成14年 & $1,894,137$ & $1,759,300$ & $3,653,437$ & 1.30 & 1.21 & 2.52 \\
\hline & 平成20年 & $1,896,434$ & $1,759,300$ & $3,655,734$ & 1.31 & 1.21 & 2.52 \\
\hline \multirow{4}{*}{$\begin{array}{l}\text { (2) } \\
\text { 将 } \\
\text { 来 } \\
\text { 施 } \\
\text { 設 }\end{array}$} & 昭和 53 年 & $1,793,857$ & $2,929,125$ & $4,722,982$ & 1.24 & 2.02 & 3.25 \\
\hline & 平成 6 年 & $1,991,852$ & $2,929,125$ & $4,920,977$ & 1.37 & 2.02 & 3.39 \\
\hline & 平成14年 & $2,227,244$ & $2,929,125$ & $5,156,369$ & 1.53 & 2.02 & 3.55 \\
\hline & 平成20年 & $2,229,945$ & $2,929,125$ & $5,159,070$ & 1.54 & 2.02 & 3.55 \\
\hline
\end{tabular}

ば，年間総取水量は，ダム利水容量の数倍となる．以上 から雑用水利用は，上水道給水の一定の割合を担う水源 ではあるが，ダムによる水資源開発の代替案としては成 立が難しいことがわかる.

\section{5. まとめ}

本研究は, 雑用水利用が推進されている福岡市を対象 にその利用量について評価を行ったものであり，以下に 示す結果が得られた.

(1) 一戸建てにおける雨水貯留施設による雨水利用につ いてモデル化し，その効果を定量的に評価すること ができた. 雨水貯留は降雨への依存性が極めて高く, 渇水時には雨水利用量が低減するが，各々の家屋に おいては，上水道給水量の $3.4 \sim 4.4 \%$ に相当する効 果が期待できる. また降水に恵まれた平成 21 年 7 月のような時期においては，7.8\%の効果となる.

（2）ビルにおける雑用水利用，雨水利用について，行政 の所有するデータを建物用途別に分析した結果，上 水道給水量の $2.26 \sim 2.52 \%$ に相当寸る効果があるも のと推計した. なお, 昭和 53 年渇水の最も給水制 限が厳しい時期にあっては, 約 4.58\%に相当する効 果がある。

(3) 平成 31 年度における雑用水利用導入施設数を過去 のデータに基づき予測し，福岡市全体の雑用水利用 量を推計した結果，今後 10 年間で上水道の約 $1 \%$
に相当する水量を供給することが可能と考えられる. 但し，その水量は, 約 1,500 千 $\mathrm{m}^{3}$ と効果は限定的 であり，福岡市において取水を予定しているダムな どの水資源開発施設の代替性は小さい.

謝辞 : 本研究を行う上で, 九州大学大学院小松利光教授, 首都大学東京河村明教授, 横山勝英准教授加御 指導を賜るとともに，国土交通省水資源政策課， 福岡市からデータを御提供いただきました。ここ に記して謝意を表します。

\section{参考文献}

1)国土交通省ホームページ，健全な水循環系構築に向けて http://www.mlit.go.jp/tochimizushigen/mizsei/junkan/index-3.html 2)城戸由能, 岡 太郎, 深尾大介, 住宅地における発生源別懸 濁態污濁物質の流出解析と発生源対策の評価，水工学論文集， 第48巻, pp.1453-1458, 2004.2.

3) 渡辺亮一，山嵪惟義，皆川朋子，伊豫岡宏樹，山下輝和，岩 田和也，流域治水を目的とした家庭用雨水貯留タンクの利用 実態把握, 土木学会第66回年次学術講演会, VII-001, pp1-2, 2011.9.

4)佐藤 寬, 再生水利用システムに関寸る研究，中央学院大学 社会システム研究所 第10巻第2号, pp.83-97, 2010.3.

5)平成20年版日本の水資源，国土交通省土地 - 水資源局水資源 部, pp.27-28, 2008.8.

6)閣議決定:利根川水系及び荒川水系における水資源開発基本計 画, 2008.

7)和田安彦, 三浦浩之, 村岡治道:雨水利用中水道システム導入 による都市水循環適正化の研究，土木学会論文集 No.587/VII -6, pp.27-36, 1998.

8)和田安彦，三浦浩之，多田律夫，尾崎平:節水型都市構築のた めの都市内水資源有効利用の研究，土木学会論文集 No.622/ III-11, pp.59-71, 1999.

9)江藤岡治, 栗田秀明:雨水貯留施設の利水効果, 第31回水理講 演会論文集，pp.283-286，1987.

10)社団法人雨水貯留浸透技術協会:雨水利用ハンドブック， pp.66, 1998.

11)国土交通省水資源政策課:平成21年度雨水 - 再生水の有效利 用普及方策検討業務報告書, 2010 .

(2011. 9. 30受付) 